\title{
PERSUASÃO E DINAMISMO PSÍQUICO: UMA PERSPECTIVA MULTIDISCIPLINAR E HISTÓRICA ${ }^{1}$
}

\author{
Marina Massimi
}

Resumo: Pretende-se evidenciar, numa perspectiva multidisciplinar e histórica, o processo que transformou o destinatário da persuasão - de sujeito ativo e crítico em consumidor passivo do produto. Na história da cultura ocidental, opõem-se duas concepções diversas do processo da persuasão: de um lado, entende-se que esta deva proporcionar uma experiência ao sujeito concebido como receptor ativo e intencional dos estímulos advindos do mundo externo, corpo vivente e espiritual (dotado de capacidade de juízo e decisão); do outro, vê-se a persuasão como indução de experiência num sujeito considerado como mero receptor passivo dos estímulos externos, corpo determinado pelo mecanismo das reações.

Palavras-chave: Persuasão. Dinamismo psíquico. Subjetividade.

O objetivo deste trabalho é evidenciar, numa perspectiva multidisciplinar e através da história, alguns aspectos do processo que transforma o destinatário da persuasão - de sujeito ativo e crítico em consumidor passivo do produto.

Do ponto de vista metodológico, abordar a questão da comunicação de informações e do processo persuasivo que se destinam a induzir ou modificar comportamentos sociais e pessoais, visando ao indivíduo como consumidor

1 Referimo-nos aqui ao trabalho "A pessoa como sujeito da experiência: um percurso na história dos saberes psicológicos", de Marina Massimi e Miguel Mahfoud, apresentado no Congresso Internacional de Filosofia - Pessoa e Sociedade realizado em Braga, Portugal, em novembro de 2005. 
de produtos de mercado, implica em considerar o imbricamento de várias áreas de estudo do homem e de sua capacidade comunicativa e discursiva, tais como a psicologia, a sociologia, a ética, a filosofia do conhecimento e a retórica.

Analisar o processo histórico tem relevância para o presente na medida em que as possibilidades proporcionadas pela história da cultura ocidental estão ainda hoje disponíveis para a opção do homem contemporâneo. A análise assim conduzida evidencia que, na história da cultura ocidental, opõem-se duas diversas concepções do processo de comunicação visando à persuasão: de um lado, entende-se que a persuasão deva proporcionar uma experiência ao sujeito concebido desde o início como receptor ativo e intencional dos estímulos advindos do mundo externo, corpo vivente e espiritual (ou seja, dotado de capacidade de juízo e decisão); do outro, uma visão da persuasão como indução de experiência num sujeito considerado como mero receptor passivo dos estímulos externos, corpo determinado pelo mecanismo das reações.

A nosso ver, a diferença entre as duas concepções deve-se às mudanças de sentido acerca das concepções de experiência, sendo estas também relacionadas às teorias do conhecimento e, consequentemente, aos métodos de comunicação visando à persuasão. ${ }^{1}$

Portanto, ao considerar o processo de comunicação cuja, finalidade é persuadir o destinatário para dispô-lo a experimentar um certo objeto ou situação, cabe, antes de mais nada, aprofundar o que se entende por experiência.

Concepções naturalistas de experiência e métodos de persuasão decorrentes

No contexto hodierno, encontram-se algumas reduções da concepção de experiência (Molioli, 1992), que, por sua vez, fundamentam-se em alicerces teóricos propostos pelas filosofias modernas e contemporâneas. Na mentalidade moderna do Ocidente, a experiência é reduzida ao significado emocional, como algo que se adverte imediatamente e de modo espontâneo, determinada pelo contexto, interno ou externo, mero "sentir", não possuindo rigor ético pelo fato de nela o sujeito não estar presente ativamente com sua liberdade e consciência, apenas acusando de modo passivo os próprios movimentos psíquicos; ou, ainda, a experiência é tomada como um "provar" sem razões. Na cultura contemporânea, assiste-se também à redução da experiência a representação, concebida como puro processo simbólico concebido desvinculado de um sujeito pessoal.

Todas essas posições têm suas raízes em algumas filosofias da Modernidade que, diluindo a conexão entre pensamento e experiência, designaram com o termo experiência uma concepção do real elaborada 
pelo homem através dos métodos de conhecimento escolhidos para tanto, dentre os quais o mais fidedigno é o experimento científico.

Conforme assinala Arendt (1999), a revolução científica e o surgir da mentalidade da Idade Moderna comportam, a partir do século XVI, a entrada, na cena da história, do homo faber, capaz de fazer e de fabricar inclusive a si mesmo. Essa nova visão do mundo acarreta - como conseqüência - uma nova concepção do conhecimento, segundo a qual a verdade e a realidade não são dadas, nem se revelam imediatamente na aparência. A Modernidade questiona a certeza de que "os sentidos como um todo integram o homem à realidade que o rodeia" (p. 287). Conseqüência disso é que se perde a nítida separação entre ser e aparência.

René Descartes (1596-1650), introduzindo a dúvida metódica, resolve-a afirmando que os processos que se passam na mente do homem são dotados de certeza própria e podem ser investigados, de modo que o homem, e não a realidade, passa a ser a fonte da certeza. O pressuposto implícito dessa doutrina é que a mente pode conhecer apenas aquilo que ela mesma produz e retém dentro de si, sendo a ciência matemática o campo exemplar desse poder. Dilui-se a conexão entre pensamento e experiência dos sentidos, substituída pelo mundo da experimentação científica. O filósofo inglês David Hume (1711-1776/1972), no Tratado da natureza humana, propõe-se a analisar seriamente a natureza do entendimento humano, utilizando-se do "espírito de exatidão e do raciocínio", segundo a hipótese de que a experiência humana, assim examinada, possa ser compreendida da mesma forma que o mundo natural. Assim, "a existência de qualquer ser somente pode ser provada mediante argumentos derivados de sua causa ou de seu efeito e estes argumentos se fundam inteiramente na experiência", e não no raciocínio a priori. Pois "é unicamente a experiência que nos ensina a natureza e os limites da causa e do efeito, e permite-nos inferir a existência de um objeto partindo de um outro" (p. 13). Inclusive, esse conhecimento experimental abarca também os fenômenos humanos: “Tal é o fundamento do raciocínio moral que constitui a maior parte do comportamento humano e que é a fonte de todas as ações e comportamentos humanos" (p. 13). Em suma, nas filosofias da Modernidade, o termo experiência passa a designar a concepção do real que o homem elabora através dos métodos de conhecimento escolhidos para tanto, dentre os quais o mais fidedigno é o experimento científico.

Essa posição encontrará sua continuidade no século XIX na filosofia positivista de Comte e Spencer, para os quais a ciência é o único saber que permite apreender a experiência de modo unificado (VanniRovighi, 1999). Os inícios da psicologia moderna são marcados pela eliminação da relação entre sujeito e objeto do conhecimento na gênese da experiência e, portanto, pelo ocultamento da presença do sujeito ativo na elaboração da mesma. W. James, por exemplo, elimina o papel 
ativo do sujeito na elaboração da experiência, sendo este concebido como mero receptor biológico passivo das influências do meio ambiente e sendo negado em seu ser pessoal (James, 1989).

Hoje, o entendimento da experiência como um mero e reativo provar, tem conseqüências importantes no plano da ética e da retórica. No plano ético, predomina a tendência que Maclntyre (2001) denomina de "emotivismo" e que consiste"na doutrina segundo a qual todos os juízos valorativos e, mais especificamente, todos os juízos morais não passam de expressões de preferência, expressões de sentimento ou atitudes" ( $p$. 30), não sendo nem verdadeiros nem falsos. Não existe, portanto, justificativa racional para a existência de padrões morais objetivos. Na sociedade contemporânea, essa teoria é personificada por algumas figuras que ocupam papéis relevantes, entre eles o administrador e o terapeuta: neles a diferença entre relação manipuladora e não-manipuladora é obliterada, tratam dos fins como fatos consumados fora de sua alçada e ocupam-se de técnicas, de eficiência. São figuras incontestáveis que nunca se engajam num debate moral e que declaram "restringir-se àqueles domínios nos quais a concordância racional é possível" (p.63), ou seja, na perspectiva deles, "ao domínio dos fatos, dos meios, da eficiência mensurável."Na visão emotivista, o eu é desprovido de critérios racionais para julgar. Esse eu sem conteúdo próprio "pode ser então qualquer coisa, pode assumir qualquer papel, ou adotar qualquer opinião, porque não é, em si e para si, nada" (p.66). Maclntyre aponta que os dois teóricos mais lúcidos dessa posição foram Jean Paul Sartre e Ervin Goffman. Do ponto de vista social, uma subjetividade assim definida sente-se totalmente à vontade no mundo social contemporâneo das sociedades desenvolvidas. O mundo social contemporâneo, por sua vez, bifurca-se, por um lado, num domínio organizacional onde os fins são dados como fatos consumados e não estão disponíveis para a análise racional e, por outro, num domínio do 'pessoal', onde não é possível nenhum posicionamento racional. Desse modo, por um lado, "surgem os autoproclamados protagonistas da liberdade individual; do outro lado, os autoproclamados protagonistas do planejamento e da regulamentação" (p. 70), verificando-se uma surpreendente concordância entre dois modos aparentemente opostos da vida social: o modo das opções livres e arbitrárias de cada um e o modo da soberania da burocracia, destinada a limitar a anarquia dos interesses próprios.

Encarando esse panorama, também Hanna Arendt (1999), lamenta "a marcante perda de experiência humana acarretada por esta marcha de acontecimentos" (p. 335): “o próprio pensamento, ao tornar-se mera previsão de conseqüências, passou a ser função do cérebro, com o resultado de que se descobriu que os instrumentos eletrônicos exercem essa função muitíssimo melhor do que nós. A ação logo passou a ser e ainda é concebida em termos de fazer e de fabricar" (p. 335). Assim, sen- 
do a vida pessoal reduzida ao processo vital da espécie, a única decisão do indivíduo é a de deixar-se levar e "aquiescer num tipo funcional de conduta entorpecida e tranqüilizada". E conclui:"o problema das modernas teorias do behaviorismo não é que estejam erradas, mas sim que podem vir a tornarem-se verdadeiras, que realmente constituem as melhores conceituações possíveis de certas tendências óbvias da sociedade moderna.É perfeitamente possível que a era moderna venha a terminar na passividade mais mortal e estéril que a história jamais conheceu" (pp. 335-336). A destruição de toda relação com a realidade é para Arendt a introdução ao totalitarismo, pois com isso "os homens perdem a capacidade de sentir e de pensar" (Arendt, 2000, p. 525). Pois "o súdito ideal do governo totalitário não é o nazista convicto nem o comunista convicto, mas aquele para quem já não existe diferença entre o fato e a ficção (isto é a realidade da experiência) e a diferença entre o verdadeiro e o falso (isto é, os critérios do pensamento)" (p. 526).

O ser humano que responde ao ambiente conforma-se à uniformidade da cultura de massa: a reprodução banal das cenas da vida cotidiana realizada pela indústria da comunicação marca a dissolução da individualidade. Destituído de sua capacidade de juízo, o homem fica entregue ao poder.

Nesse contexto, a retórica e a comunicação, visando à persuasão dos destinatários, não têm a obrigação de convencer racionalmente, mas apenas de proporcionarem apelos aos sentidos e aos afetos para captar adesões. Dessa forma, esses apelos, que eram apenas um dos aspectos do processo tradicional da persuasão, tornam-se um fim em si mesmos.

$\mathrm{Na}$ visão de Schopenauer (citado por Nietzsche, 1995), por exemplo, "a eloquência é a faculdade de fazer partilhar as nossas opiniões e a nossa maneira de pensar a propósito de uma coisa, de lhes comunicar os nossos próprios sentimentos, de pô-los em sintonia conosco. O resultado visado seria o de fazer penetrar por meio das palavras as nossas idéias nos cérebros dos outros, com uma força tal que os seus próprios pensamentos se desviem do seu curso primitivo para seguir os nossos, sendo a obra tanto mais perfeita quanto o curso das suas idéias diferiram anteriormente das nossas".

Nesse sentido, não parece constituir uma real alternativa a este cenário a assim chamada Nova Retórica de Perelman: apesar desse autor se colocar em continuidade com o aristotelismo e a tradição clássica, todavia, ao propor como critério para a convicção o "verosímil',' plausível',"'provável", determinado pela decisão do auditório, reduz a verdade ao objeto do consenso, a opiniões geralmente aceites. Restringir o critério de validade ou justeza apenas nos termos daquilo que pensa o auditório e reduzir o entendimento do real não ao seu sentido ontológico, mas apenas no sentido daquilo que um auditório entende ou acredita ser real, parece-nos manter o sujeito na posição que Arendt definira acima de "súdito 
ideal do totalitarismo". Assim, essa concepção da retórica não impede que se possa reduzi-la à "arte de enganar; à arte de usar todos os dispositivos possíveis para influenciar o auditório, apelando para os seus instintos mais baixos, ou para argumentos que parecem razoáveis mas não o são (as falácias)".2

Um aspecto desse processo é a modalidade com que as mídias contemporâneas utilizam-se das imagens, buscando um consenso que dispense a mobilização dos recursos intelectuais. Alerta Gusdorf (1978) que "aquele que se abandona sem defesa ao fluxo das imagens, renuncia à direção de seu próprio pensamento e aceita uma direção da consciência por intervenções estranhas" (p. 145). Pois a retórica das imagens convence pelo estímulo à afetividade em detrimento do pensamento.

A experiência e a persuasão da pessoa concebida como sujeito de juízo e de decisão

Arendt afirma que a única possibilidade do homem subtrair-se ao totalitarismo contemporâneo é a capacidade intrínseca na pessoa de pôr um novo início. Para isso, é preciso retomar o sentido humano da experiência.

Vimos que o empirismo, no início da Idade Moderna, passa a reduzir a experiência à dimensão do conhecimento sensorial - a ser testado e comprovado conforme os critérios do método científico. Esta redução foi contestada por Husserl, por ser uma "naturalização" da experiência humana. Segundo Husserl, a naturalização da experiência elimina seu sujeito, ao passo que podemos atingir a experiência somente a partir da apreensão do sujeito que continuamente a constitui. Ocupando-se especificamente da categoria experiência do ponto de vista da teoria do conhecimento, afirma que a presença do eu na elaboração da mesma permite chegar ao conhecimento e à formulação de um juízo. Para explicar isso, Husserl (1948/1995) parte do mundo da vida:"Se quisermos chegar à experiência entendida no sentido último e originário que estamos procurando, esta não pode deixar de ser a experiência originária que se dá no mundo da vida, a qual ainda nada sabe a respeito das idealizações embora seja seu fundamento necessário" (p.41). Já no nível da percepção, pode-se acusar a existência do sujeito ativo:"o perceber é uma operação ativa do eu" (p. 65), não apenas um elemento passivo da consciência, mas fruto de sínteses dotadas de força afetiva. Segundo Husserl, o "conceito normal de experiência (percepção, recordação etc.) indica a experiência ativa que depois se desenvolve como experiência explicativa" (p. 72).

A Argumentação na Comunicação Empresarial 2001 - esidério Murcho, disponível em http:// critica.no.sapo.pt/fil_comunicacaoempresarial.html 
A concepção da experiência implicando o sujeito ativo e capaz de juízo encontra-se também em teorias da tradição cultural ocidental. $\mathrm{Na}$ visão própria da filosofia ocidental européia (clássica, medieval e humanista), a experiência era entendida segundo dimensões diversificadas, o termo experiência referia-se tanto ao conhecimento sensorial e prático quanto à verificação e prova, ou mesmo ao conhecimento interior.

Santo Agostinho, nos Solilóquios, define a experiência em termos de conhecimento sensorial. A vivência da experiência sensorial, porém, deve ser analisada em toda a sua complexidade. A esse respeito, Agostinho coloca, no capítulo sexto, uma importante distinção entre olhar e ver:"as coisas são iluminadas pelo sol para que possam ser vistas, assim, como o é a terra e tudo o que é terreno; mas Deus é quem ilumina. Assim, eu, a razão, estou nas mentes como a visão nos olhos, como tampouco olhar e ver. Por isso, a alma precisa de três coisas: ter olhos dos quais possa usar bem, olhar e ver" (p. 30). Tais afirmações implicam que toda experiência sensorial (olhar) possui uma dimensão racional.

Na Suma Teológica, Tomás de Aquino define o homem como ser orgânico-psíquico e espiritual (sínolo) cujo dinamismo é voltado para a busca da felicidade e refere-se ao termo experiência no sentido aristotélico de conhecimento pelos sentidos (Vol. 2, Parte 1, qu. 54, art. 3). Nesse contexto, os sentidos não são apenas os externos ligados aos cinco órgãos sensoriais, mas também há quatro sentidos internos, a saber, fantasia, cogitativa (ou ratio particularis), memória e senso comum. Cada um deles assume uma função específica na produção do conhecimento: o senso comum realiza uma primeira unificação das informações sensíveis transmitidas pelos sentidos externos, a fantasia ocupa-se de sua unificação num quadro espaço-temporal, a memória armazena e ordena as informações em imagens e a potência cogitativa proporciona uma primeira intelecção dos elementos não sensíveis, realizando um primeiro nível de reconhecimento do universal no sensível. A potência cogitativa é ratio particularis, o conhecimento racional das coisas específicas, uma espécie de continuação do espírito na sensibilidade que apreende as coisas particulares, manifestando nelas o universal. Assim, mesmo que a potência cogitativa pertença ao âmbito do pré-racional, apresenta-se já orientada para o todo, de modo que a sensibilidade é ela também plasmada pelo espírito. Na continuidade entre sensibilidade e intelecto, a potência cogitativa é o meio onde o espírito e a sensibilidade unem-se, para formar um único conhecimento humano. Pois o pensamento, enquanto permanece num corpo não glorioso, necessita sempre voltar ao sustento do sensível e do fantástico para entender. A memória e a cogitativa fundamentam a virtude da prudência, a qual, por sua vez, discerne o bem e o mal e sugere a escolha do bem concreto, orientando a ação. 
Segundo essa doutrina, o recurso da persuasão pela arte retórica subentende numa concepção universalista da palavra, a qual, espelhando a razão, torna-se portadora de verdades. Seu destinatário é o ser humano enquanto sujeito de juízo e de livre arbítrio. Na prática retórica, a palavra encarnada na elocução penetra os ânimos e atinge o plano moral, tornando-se, assim, ética. A palavra eloqüente não apenas veicula a coisa, mas sugere também comportamentos diante dela. A retórica, portanto, associa a razão à verdade e à moralidade, chamando em causa a liberdade como condição de tal associação.

Por isso, persuadir nunca pode identificar-se com a manipulação dos destinatários, pois deve induzir sempre neles uma atitude de verificação racional da experiência proposta e uma decisão diante dela.

Finalizando, uma concepção de experiência que implique o sujeito enquanto capaz de juízo e possuidor de um critério interno para julgar e decidir acarreta que a persuasão nunca possa coincidir com a manipulação da pessoa. Ao passo que uma concepção de experiência que implique o sujeito como mero receptor de estímulos proporcionados pelo ambiente externo submete-o necessariamente aos determinismos naturais, sociais e políticos. A afirmação do sujeito como destinatário ativo da persuasão passa pela educação, pela pessoa enquanto desejosa de felicidade, aberta para a realidade total, portadora de um critério de juízo e capaz de liberdade e decisão. Desse modo, põe-se um sujeito criador de cultura.

No Brasil, muitas vezes a partir de uma visão reducionista da experiência codificada e difundida pelo saber acadêmico, pensa-se o outro destinatário da intervenção social ou política e dos cuidados educacionais, ou sanitários - como um sujeito passivo e alheio à cultura. Na verdade, porém, os destinatários dessas ações e cuidados são sujeitos capazes de experiência e portadores de cultura. Precisamos respeitar, conhecer e compreender a cultura desses sujeitos e comunidades que compõem o povo brasileiro, ao mesmo tempo em que atuamos no meio dele.

\section{Persuasion and psychic dynamism in a multidisciplinary and historical perspective}

Abstract: We intend to provide evidence, in a multidisciplinary and historical perspective, the process of persuasion by which the recipient was transformed from an active and critical individual into a passive product consumer. In the history of western culture, there are two opposing conceptions regarding the process of persuasion. On the one side, it is understood that persuasion should offer an experience to the individual, who is conceived as an active and intentional receiver 
of the stimuli from the external world, a living and spiritual body (capable of judging and making decisions). On the other side, persuasion is considered an experience induction, in which the individual is considered a mere passive receptor of external stimuli, a body determined by reaction mechanisms.

Keywords: Persuasion. Psychic dynamism. Subjectivity.

\section{Consideraciones sobre persuasión y dinamismo psíquico bajo la perspectiva multidisciplinaria e histórica}

Resumen: Se pretende evidenciar bajo la perspectiva multidisciplinaria e histórica el proceso que transformó el destino de la persuasión de sujeto activo y crítico en consumidor pasivo del producto. Según la historia de la cultura occidental se oponen dos diferentes concepciones sobre el proceso de persuasión: por un lado se entiende que debe proporcionar al sujeto una experiencia, siendo concebido como receptor activo e intencional de estímulos provenientes del mundo externo, cuerpo viviente y espiritual (dotado de capacidad de juicio y decisión); por el otro se ve a la persuasión como inducción de la experiencia del sujeto, considerado como mero receptor pasivo de los estímulos externos, cuerpo determinado por el mecanismo de las reacciones.

Palabra-clave: Persuasión. Dinamismo psiquico. Subjetividad.

\section{Considerations sur persuasion et dynamisme psychique dans une perspective multidisciplinaire et historique}

Résumé: On prétend mettre en évidence, dans une perspective multidisciplinaire et historique, le processus qui a transformé le destinataire de la persuasion - de sujet actif et critique, en consommateur passif du produit. Dans I'histoire de la culture occidentale, deux diverses conceptions du processus de persuasion s'opposent : d'un côté on comprend que la persuasion doit offrir une expérience au sujet conçu comme récepteur actif et intentionnel des stimulus venus du monde externe, corps vivant et spirituel (ayant la capacité de raisonnement et décision); de l'autre côté on voit la persuasion en tant qu'induction d'expérience chez le sujet consideré comme récepteur passif des stimulus externes, corps determiné par le mécanisme des réactions.

Mots-clés : Persuasion. Dynamisme psychique. Subjectivité. 


\section{Referências}

Arendt, H. (1999). A condição humana (R. Raposo, trad.). Rio de Janeiro: Forense Universitária. (Trabalho original publicado em 1958)

Arendt, H. (2000). Origens do totalitarismo. São Paulo: Companhia das Letras. (Trabalho original publicado em 1949)

Gusdorf, G. (1978). A agonia da nossa civilização. São Paulo: Convívio.

Hume, D. (1972). Investigações acerca do entendimento humano (A. Aiex, trad.).Rio de Janeiro: Nacional.

Husserl, E.(1995). Esperienza e giudizio:ricerche sulla genealogia della logica (L.Landgrebe, Ed.).Milano:Bompiani.(Trabalho original publicado em 1948)

James, W. (1989). Princípios de psicologia (A. Barcena, Trad.). Mexico: Fundo de Cultura Económica. (Trabalho original publicado em 1891)

Maclntyre, A. (2001). Depois da virtude. Bauru, SP: Edusc. (Trabalho original publicado em 1981)

Molioli, G. (1992).L'esperienza spirituale:lezioni introduttive. Milano: Glossa.

Nietzsche, F.(1995). Da retórica (T.Cardoso e Cunha, trad.) São Paulo:Vega.

Santo Agostinho. (1998). Solilóquios e a vida feliz (A. Fiorotti, trad.). São Paulo: Paulus. (Obra original de 386 d.C.)

Santo Tomás de Aquino. (2002). Suma Teológica (Vol. 2, C. P. Pinto de Oliveira, org.e trad). São Paulo: Loyola. (Obra original de 1269)

Vanni-Rovighi, S. (1999). História da filosofia contemporânea (A.Capovilla, trad.). São Paulo: Loyola. (Trabalho original publicado em 1980)

Marina Massimi, Professora Associada da Faculdade de Filosofia Ciências e Letras da Universidade de São Paulo, Campi Ribeirão Preto. Endereço eletrônico: mmassimi3@yahoo.com

Recebido em: 30/04/2008

Aceito em: 30/10/2008 